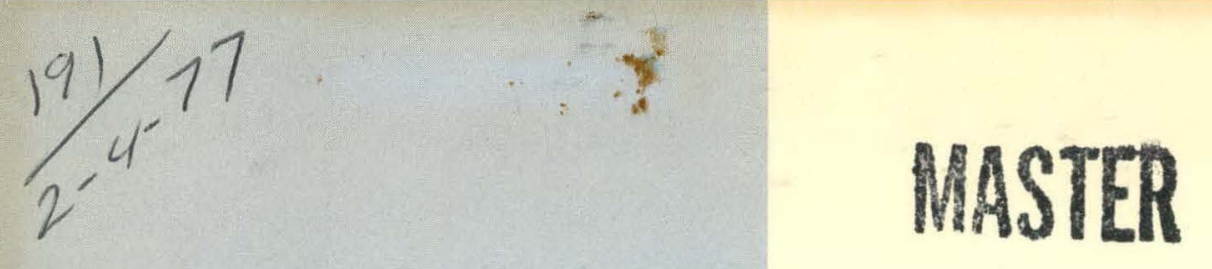

COMPENSATION FOR THE SHAPE OF A CONTOUR GRINDING WHEEL USING COMPUTER NUMERICAL CONTROL

W. E. Barkman

T. O. Morris 


\section{DISCLAIMER}

This report was prepared as an account of work sponsored by an agency of the United States Government. Neither the United States Government nor any agency Thereof, nor any of their employees, makes any warranty, express or implied, or assumes any legal liability or responsibility for the accuracy, completeness, or usefulness of any information, apparatus, product, or process disclosed, or represents that its use would not infringe privately owned rights. Reference herein to any specific commercial product, process, or service by trade name, trademark, manufacturer, or otherwise does not necessarily constitute or imply its endorsement, recommendation, or favoring by the United States Government or any agency thereof. The views and opinions of authors expressed herein do not necessarily state or reflect those of the United States Government or any agency thereof. 


\section{DISCLAIMER}

Portions of this document may be illegible in electronic image products. Images are produced from the best available original document. 
Reference to a company or product name does not imply approval or recommendation of the product by Union Carbide Corporation or the U.S. Energy Research and Development Administration to the exclusion of others that may meet specifications.

Printed in the United States of America. Available from National Technical Information Service

U.S. Department of Commerce

5285 Port Royal Road, Springfield, Virginia 22161

Price: Printed Copy $\$ 3.50$; Microfiche $\$ 3.00$

This report was prepared as an account of work sponsored by the United States Government. Neither the United States nor the Energy Research and Development Administration, nor any of their employees, nor any of their contractors, subcontractors, or their employees, makes any warranty, express or implied, or assumes any legal liability or responsibility for the accuracy, completeness or usefulness of any information, apparatus, product or process disclosed, or represents that its use would not infringe privately owned rights. 
Date of Issue: January 31, 1977

Report Number: Y-2067

Distribution Category: UC-38

\title{
COMPENSATION FOR THE SHAPE OF A CONTOUR GRINDING WHEEL USING COMPUTER NUMERICAL CONTROL
}

\author{
W. E. Barkman \\ T. O. Morris
}

Fabrication Systems Development

Y-12 Development Division

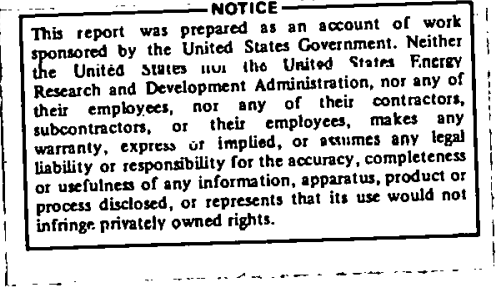

Oak Ridge Y-12 Plant

P. O. Box Y, Oak Ridge, Tennessee 37830

Prepared for the US Energy Research and Development Administration

Under US Government Contract W-7405-eng-26 


\begin{abstract}
An Allen-Bradley Company 7300 Computer Numerical Control (CNC) system has been interfaced with a two-axis machine tool in the Oak Ridge $Y-12$ Plant to utilize on-machine tool-path adjustment to compensate for parameter variations in the contour grinding process. Hemishell test parts machined without compensation for grinding wheel size or shape deviated from the desired contour by as much as $48.26 \mu \mathrm{m}$ (1.8 mils). Use of the wheel-shape compensation techniques reduced this deviation to $10.16 \mu \mathrm{m}(0.4 \mathrm{mil})$.
\end{abstract}




\section{CONTENTS}

SUMMARY .................................... 4

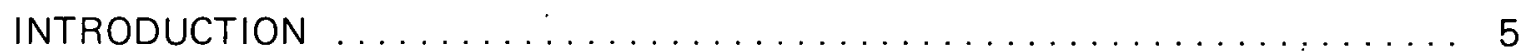

GRINDING-WHEEL COMPENSATION THROUGH

COMPUTER CONTROL $\ldots \ldots \ldots \ldots \ldots \ldots \ldots \ldots \ldots \ldots \ldots \ldots \ldots \ldots$

Experimental Work .................................. 7

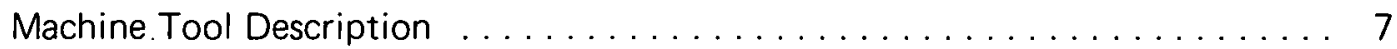

Equipment Installation and Checkout $\ldots \ldots \ldots \ldots \ldots \ldots \ldots \ldots \ldots, 8$

Grinding-Wheel-Shape Compensation Software $\ldots \ldots \ldots \ldots \ldots \ldots \ldots \ldots g$

Grinding Test Results .............................. 12

Conclusions and Recommendations ........................... 15

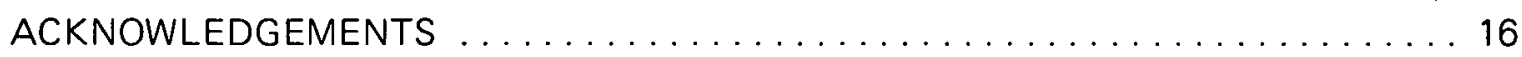

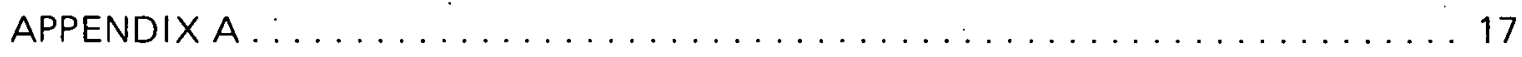

Options Available with the Computer Numerical Control System . . . . . . . . . . . 17

Ảxis Calibration ................................. 17

Switchable Inch/Metric Conversion ....................... 17

Part Program Storage and Edit . . . . . . . . . . . . . . . . . . . . 17

Pattern Repeat .................................... 17

Servo and Machine Characteristics ....................... 18

Cutter-Diameter Compensation ......................... 18

APPENDIX B ......................................... 19

Shape Compensation Algorithm ............................ 19 


\section{SUMMARY}

An Allen-Bradley Company 7300 Computer Numerical Control (CNC) system has been interfaced with a two-axis machine tool in the Oak Ridge $\mathrm{Y}-12$ Plant to utilize on-machine tool-path adjustment to compensate for parameter variations in the contour grinding process. Grinding wheel size and shape are the parameters of interest, since perturbations in these quantities will adversely affect the contour of the finished part.

On-machine grinding-wheel characterization techniques are used to define the deviations of the grinding wheel from a previously programmed norm. These data are then used during the machining pass to adjust the programmed tool path to compensate for the grinding wheel irregularities.

Hemishell test parts machined without compensation for grinding wheel size or shape deviated from the desired contour by as much as $48 \mu \mathrm{m}(1.8 \mathrm{mils})$. Use of wheol-shape compensation techniques reduced the deviation to $10 \mu \mathrm{m}(0.4 \mathrm{mil})$. Similar improvements are obtained with wheel-shape deviations as large as $686 \mu \mathrm{m}$ (27 mils). 


\section{INTRODUCTION}

Many types of materials used in high-temperature applications are incompatible with conventional single-point machining. Most ceramic materials fall into this category. To obtain the normally required finish and contour accuracy, parts fabricated from ceramic materials must be contour ground.

Contour grinding, as performed in the Oak Ridge $Y-12$ Plant, $(a)$ is not a form-grinding process in which a shape is dressed onto the grinding wheel and the mirror image of this shape is ground into the part surface. Instead, this contour-grinding operation moves a standard grinding wheel with a radiused face through a tool path very similar to the tool path that would be used on a numerically controlled lathe to single-point turn the same part configuration. The path taken by the contour grinding wheel in grinding a hemishell part is illustrated in Figure 1.
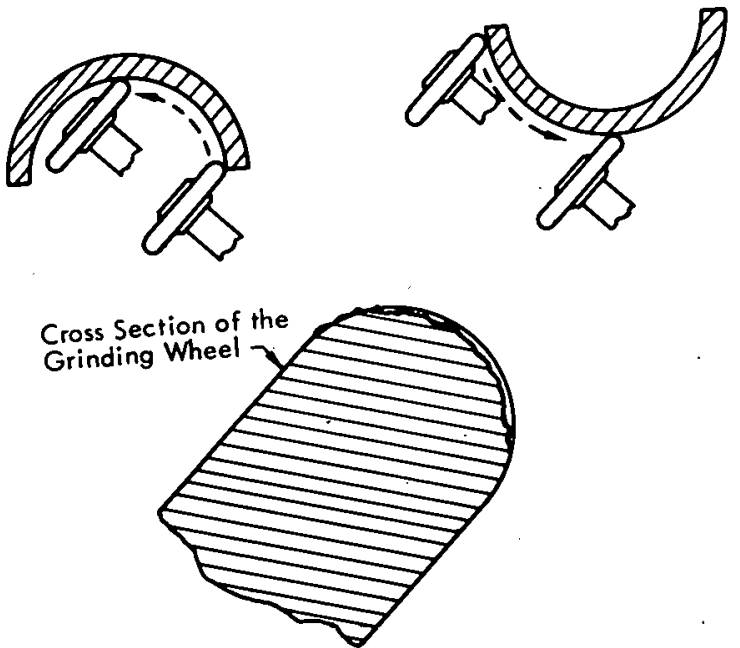

161270

This grinding process has been used Figure 1. PATH TAKEN BY A CONTOUR GRINDING effectively on numerous parts made from WHEEL.

ceramic materials. However, several sources of contour deviation are found that are either not found in single-point turning operations or, if found, are not significant sources of error. The major sources of error are: (1) setup errors in locating the relative position of the unground part and the grinding wheel on numerical control (NC) machines, (2) poor tolerances on the radiused face of the as-purchased grinding wheels, and (3) deterioration of the shape of this radiused face due to wheel wear.

In order for contour grinding to be used to attain the same level of accuracy as single-point turning, these sources of error must be eliminated; or, at least, the effects of these errors must be reduced to a more acceptable level.

Error reduction has been accomplished to some extent through the utilization of automatic grinding-wheel setters and wheel-trueing procedures. (b) However, many types of diamond grinding wheels normally used on ceramic materials are not susceptible to trueing operations and must be used with the existing face radius and tolerance level. If the desired contours

(a) Operated by the Union Carbide Corporation's Nuclear Division for the US Energy Research and Development Administration.

(b) An Ultrasonic-Acoustic Grinder Setting Station, Y-1935; Union Carbide CorporationNuclear Division, Oak Ridge Y-12 Plant, Oak Ridge, Tennessee; March 26, 1974. 
are to be ground with this nontrueable wheel or a badly worn wheel, some method of compensating for the poor initial wheel shape and/or the change in shape due to wheel wear is required. To accomplish this objective, a computer numerical control (CNC) was interfaced with a two-axis machine tool and methods were developed to make on-machine tool-path adjustments. 


\section{GRINDING-WHEEL COMPENSATION THROUGH COMPUTER CONTROL}

\section{EXPERIMENTAL WORK}

\section{Machine Tool Description}

Figure 2 presents an overall view of a typical two-axis T-base machine tool which is used in the $\mathrm{Y}-12$ Plant for the fabrication of precision parts. The work spindle is mounted on top of

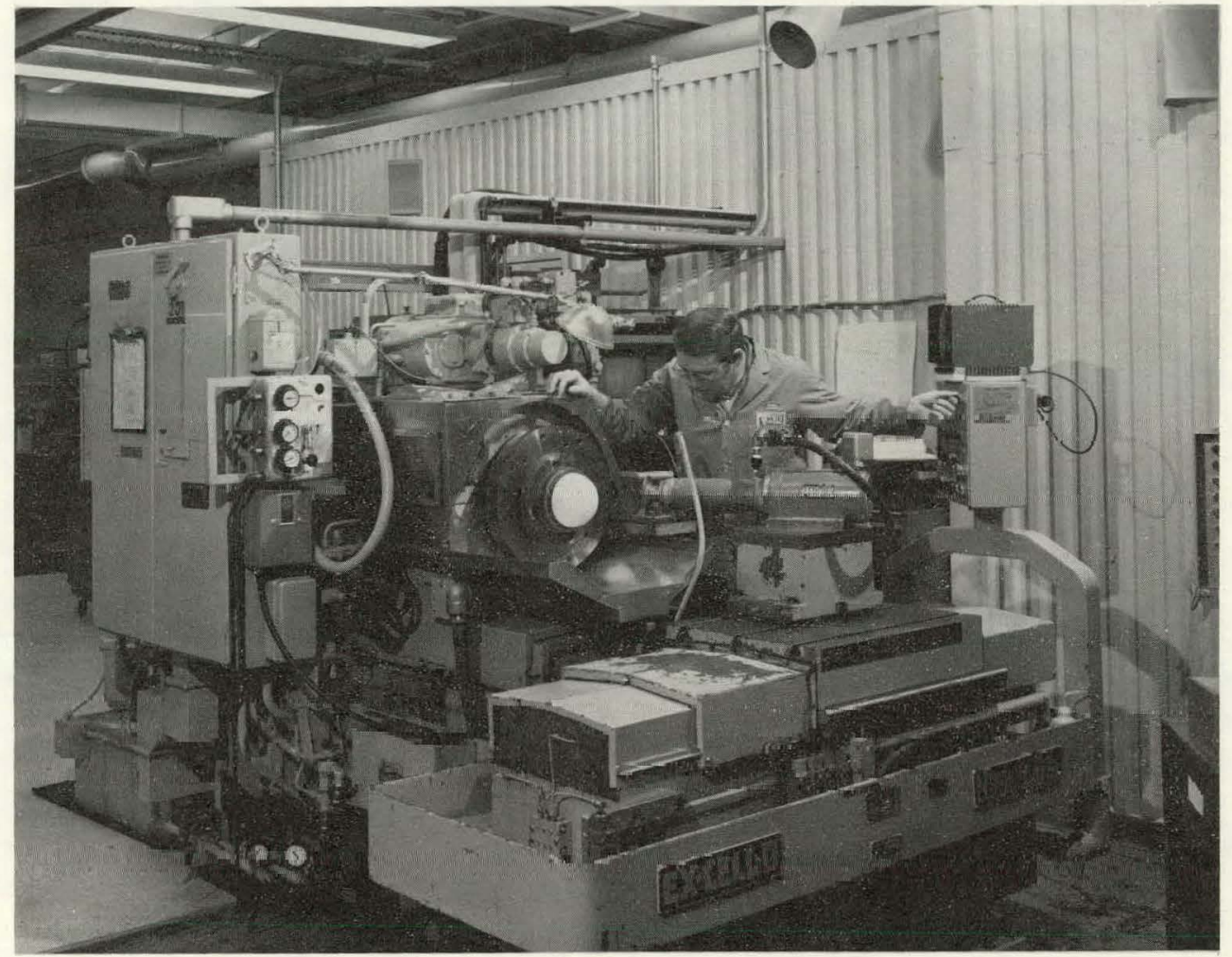

Figure 2. A TYPICAL TWO-AXIS T-BASE MACHINE TOOL.

158692

the work slide ( $Y$ axis), while the cutter (the grinding wheel in this study) is mounted on top of the tool slide ( $X$ axis). Linear slide motion is obtained by using a ballnut/leadscrew combination which is driven by a hydraulic motor. The ball-bearing spindle is also driven by a hydraulic motor.

The raw material, from which a part is to be fabricated, is mounted on the work spindle, then the machine axes are moved in a manner that directs the cutting tool to follow the desired tool path around the rotating workpiece. The relative motion of the tool and workpiece generates a figure of revolution such as a cylinder, cone, or sphere. Motion of the individual axes is controlled by a system which receives its input from a previously prepared punched tape. This punched tape, called a part program tape, is generated by using a computer program whose input is a description of the desired part shape. 


\section{Equipment Installation and Checkout}

To investigate the potential of computer numerical control ( $\mathrm{CNC}$ ) for grinding-wheel-shape compensation, an Allen-Bradley $7300 \mathrm{CNC}$ was interfaced with an existing Ex-Cell-O 921 two-axis turning machine (see Figure 3 ).

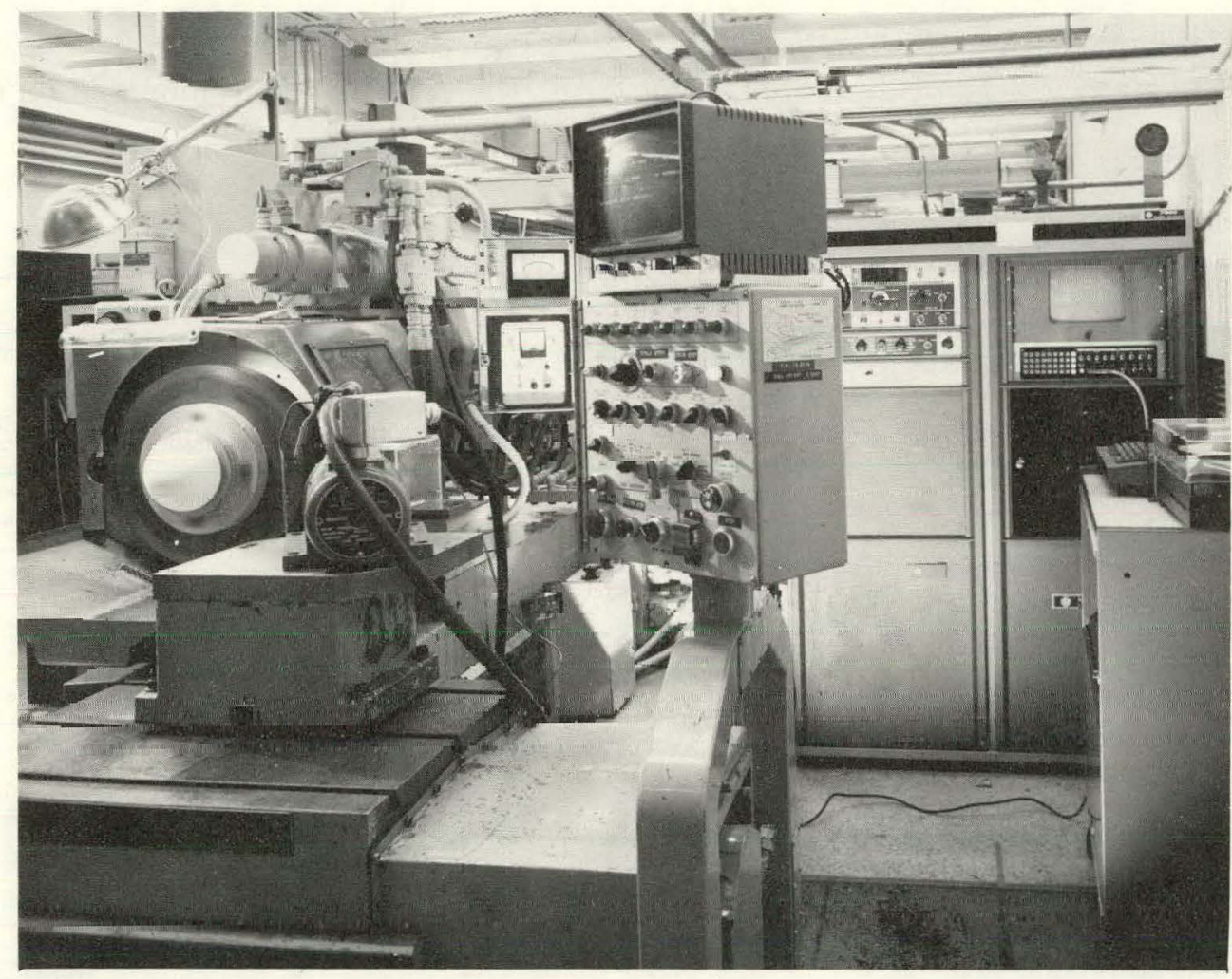

158689

Figure 3. AN EX-CELL-O 921 CONTOUR GRINDER AND AN AIIFN-BRADLEY 7300 COMPUTER INUIVIEKILAL LUNTROL UNIT.

The machine used in this work had a ball-bearing spindle, cam-follower lead-screw compensation, a 20 -microinch servo resolution, $635 \mathrm{~mm}$ (25 in) of travel on the $X$ axis, and $381 \mathrm{~mm}$ (15 in) of travel on the $Y$ axis. The basic CNC system had a hydraulic servo interface, electric spindle drive, a $24-\mathrm{V}$-dc input/output interface, a 10-microinch programming resolution, a 2.5-microinch servo resolution, cutter compensation, a tape punch, and $16 \mathrm{~K}$ of computer core and computer diagnostics in addition to the usual NC features.

Manual modifications to the machine consisted of installing flex bolts on the axes leadscrew ballnuts, remachining the leadscrew compensation cam, and changing the resolver gears to accommodate the increased servo resolution. (Only a factor-of-two gearing change was required since the Allen-Bradley 7300 resolver feedback is based on 4000 "counts" per revolution of the resolver shaft rather than the 1000 counts used by the control system that originally came with the machine.) 
Electrical modifications to the machine wiring primarily consisted of replacing the resolvers on each axis, modifying the existing pendant panel to duplicate the most-used CNC functions, and adding two limit switches to each axis. The additional limit switches are used to provide a marker signal for the resolver-null-based axis-home circuitry. In addition, a 9-inch cathode-ray-tube (CRT) monitor was mounted on top of the pendant panel for the convenience of the operator.

The CNC utilizes a CRT display of axes positions, distance to go, following error, program data blocks, and miscellaneous status information. Other features include: inch-to-metric conversion, cutter compensation, part-program storage and editing, axis calibration, pattern repeat, storage of servo and machine characteristics, and tape-punch capability. These features are described in more detail in Appendix A.

The servo system adjustment was performed using the CRT-displayed axes-following error. A laser interferometer was used to perform the position accuracy setup and to obtain data for fabricating the leadscrew compensation cam. The compensated leadscrew error was about $3.81 \mu \mathrm{m}(150 \mu \mathrm{in})$ for the $\mathrm{X}$ axis and about $2 \mu \mathrm{m}$ (80 $\mu \mathrm{in})$ for the $\mathrm{Y}$-axis.

The basic contouring accuracy of the machine was characterized by diamond turning a 12-inch-diameter outer contour (OC). The best-fit contour from equator to pole was inspected to be about $3 \mu \mathrm{m}$ (120 $\mu \mathrm{in})$. The part roundness at the equator was $1 \mu \mathrm{m}$ (40 $\mu \mathrm{in})$. The polar region of the part exhibited a spiral pattern which was attributed to work-spindle axial motion.

The CNC system was originally ordered without many of the software options that are now in use. Some of the features, which were added later, were standard vendor options while others, such as the wheelset software and the grinding-wheel-shape compensation software, were special orders. In the case of the special software packages, purchase requisitions were written, describing the software completely, after discussing the applications with the Allen-Bradley computer programmers.

\section{Grinding-Wheel-Shape Compensation Software}

The contour-grinding process utilizes an $X-Y$ machine tool to move the grinding wheel through the desired tool path. Figure 4 provides a view of a typical diamond grinding wheel, which is fabricated so that its face has a circular shape (as shown by the inspection clips). During a machining pass, the contact point between the rotating grinding wheel and the part changes, as illustrated in Figure 1. The computer program, which is used to generate the machining part program tape, takes into account this change in contact points; and, it does so by assuming a grinding wheel with a face radius that is a specific size and perfectly round. However, the actual size and shape of the grinding wheels used in production vary considerably from the specified parameters due to two important factors: (1) inaccuracies in the wheel fabrication process, and (2) wear that occurs during the machining process. Typically, size variations of $\pm 50.8 \mu \mathrm{m}$ ( \pm 2 mils) and shape variations of $\pm 12.7 \mu \mathrm{m}( \pm 0.5 \mathrm{mil})$ are encountered with new "as-purchased" 
wheels. Worn wheels have even greater variations. Use of these grinding wheels produces parts that do not meet the required tolerance, as noted in Figures 5 and 6 .

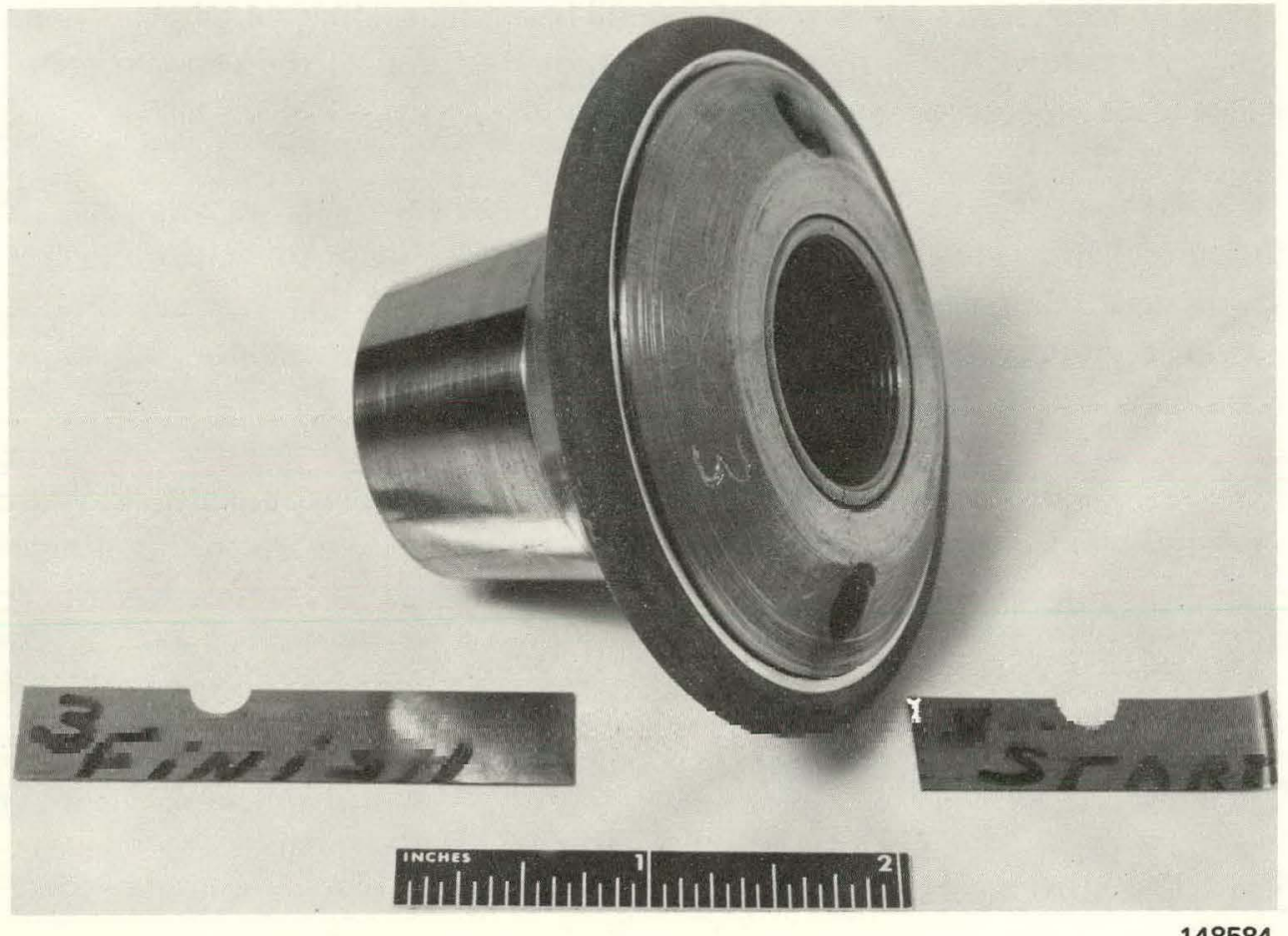

Figure 4. A TYPICAL DIAMOND GRINDING WHEEL.

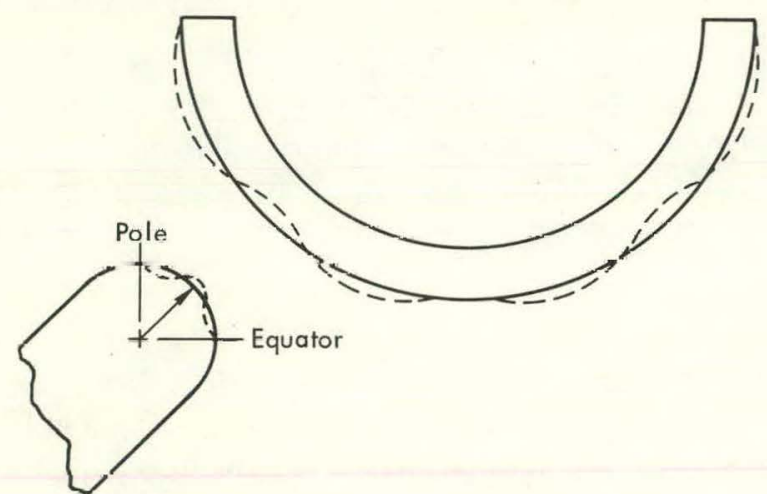

161269

Figure 5. PART-CONTOUR ERROR DUE TO AN IRREGULAR WHEEL RADIUS.

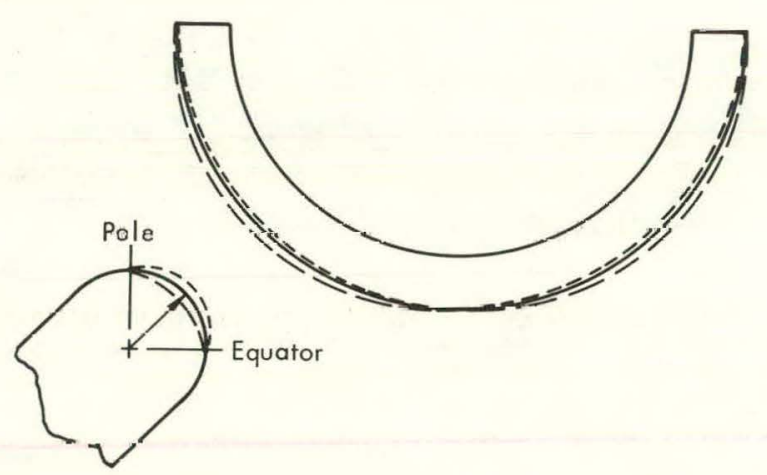

161272 Figure 6. PART-CONTOUR ERROR DUE TO AN INCORRECT WHEEL SIZE.

In the past, two techniques have been used to compensate for the difficulties just mentioned:

1. "Shimming" the part-program tape so that the programmed wheel radius represents a best fit to the inspected wheel radius. However, this approach necessitates a separate part-program tape for each grinding-wheel size. 
2. Dressing the grinding wheels to a specific size and radius. Unfortunately, if the grinding wheel is "soft" enough to be easily dressed, then it also exhibits excessive wheel wear when machining hard materials.

In order to compensate for errurs in the grindirry wlıel size and shape, a whicel shape compensation technique was developed that utilizes the CNC control system and an ultrusunic/acoustic wheel setter. Figure 7 shows the wheel and wheel setter during a setup cycle.

The wheel setter consists of a steel ball that is acoustically coupled to a piezo-electric crystal via a support post. The ceramic crystal is split in half and connected differentially in series for use with a differential amplifier. The acousticemission-detector assembly and ballsupport post are mounted in a yoke having high ultrasonic losses; which, in turn, reduces the coupling due to external shock and vibration, but provides a stable molınting medium for attaching the setter to the machine.

When the rapidly rotating grinding wheel touches the wheel-setter ball, the induced

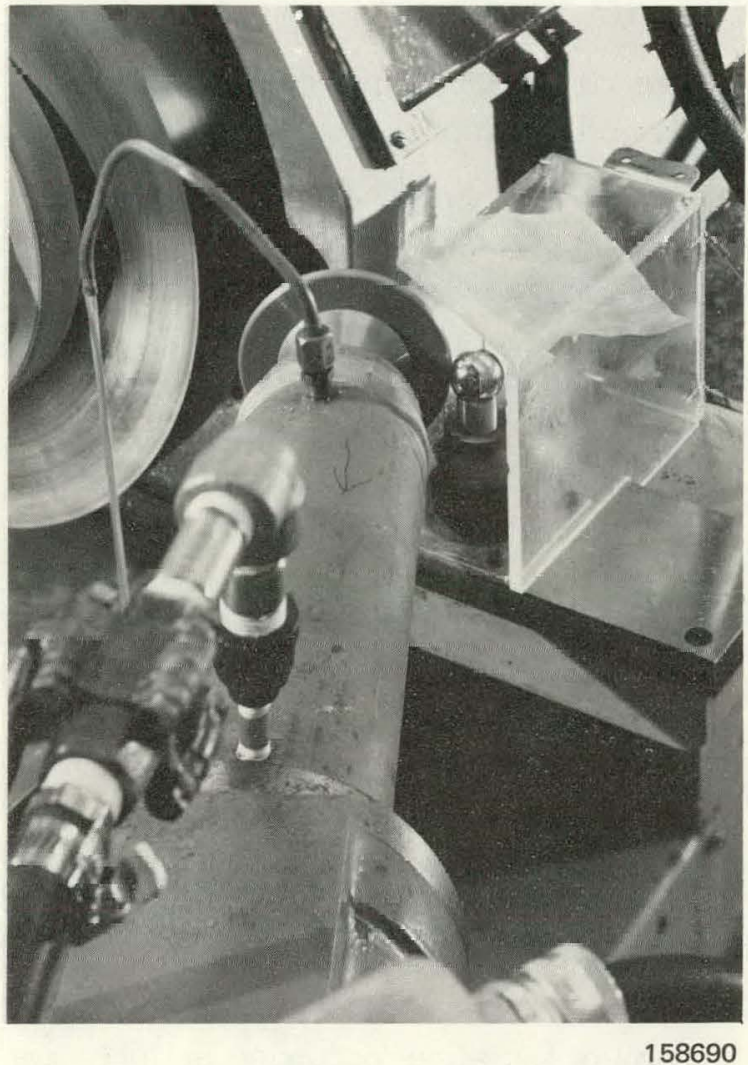

Figure 7. GRINDING WHEEL AND WHEEL SETTER DURING A SETUP CYCLE. vibration causes the ceramic crystal to send an electrical signal to the associated electronics, which tells the CNC that contact has occurred. This action allows the operator to use the wheel setter to determine the relative location of the grinding wheel on the machine and to properly position the grinding wheel in order to fabricate the desired part.

The exact location of the wheel setter, with respect to the machine work spindle face and center of rotation, is obtained from experimental data. The location of the grinding wheel relative to the work spindle is obtained during the wheel-set cycle when the machine axes are used individually to move the rotating grinding wheel toward the wheel-set ball. Upon contact between the ball and wheel, the CNC notes the axis position and establishes a relative zero pusition for the particular axis, as illustrated by Figure 8.

A similar technique is used to determine the effective shape of the grinding wheel, as noted in Figure 9. Following a wheel-set operation (which establishes the axes relative zero points by contacting the wheel-set ball at zero and ninety degrees), the rotating grinding wheel is moved into the wheel-set ball at points between the zero and ninety-degree setup locations. 
A typical wheel-characterization pass requires approximately twelve minutes and has the CNC gather data on the effective radius of the grinding wheel at every three degrees between the zero and ninetydegree points, resulting in thirty-one datacollection locations.

Following contact between the grinding wheel and wheel-set ball during the data-collection pass, the CNC calculates the appropriate offset in effect at each location. Issing the algnrithm discussed in Appendix B. The calculated offsets are stored in a cutter-compensation table and utilized by the $\mathrm{CNC}$ during the machining pass to adjust the programmed tool path to compensate for the irregularities in the grinding wheel size and shape. Figure 10 indicates the contour variation that would be obtained when using a wheel with a face radius different from that programmed on the part tape. As can be seen, this variation would be a function of the latıtude of the contact point, with the maximum variation occurring at forty-five deyrees. The offset due to wheel size alone, at the forty-five-degree latitude, is forty percent of the difference between the two radii.

During the data-collection pass, the software checks for erroneous data due to environmental disturbances. The $\mathrm{CNC}$ repeats the characterization cycle for each particular point at which a false trigger is transmitted by the tool setter, ensuring that the compensation values are not influenced by environmental disturbances.

\section{Grinding Test Results}

Figure 11 is an error-table plot that was generated using a grinding wheel with an

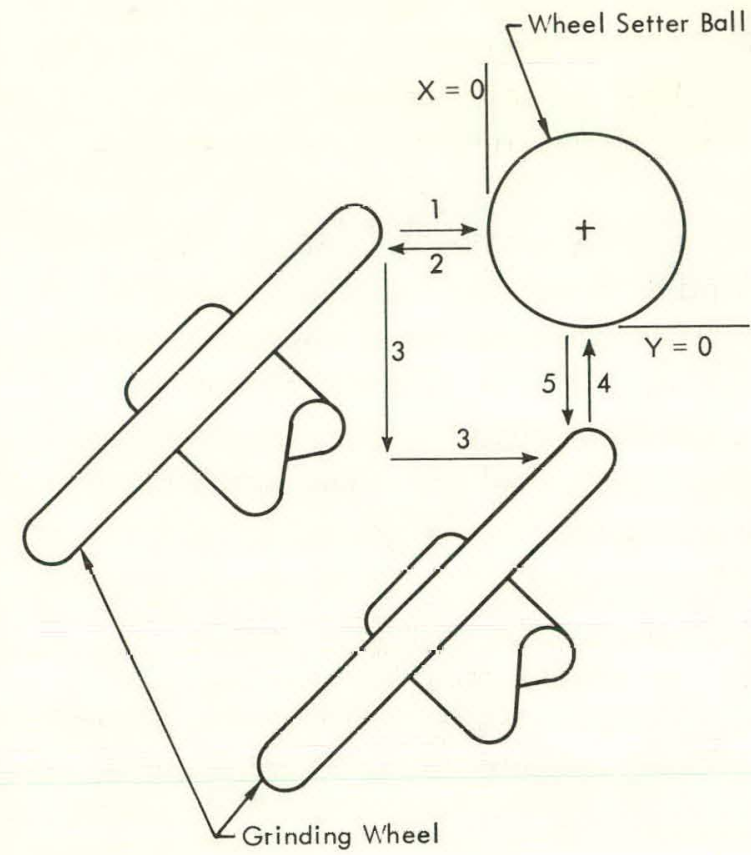

Steps in the Cycle

1. Approach the ball, using the $X$ axis only.

2. Retract from the ball following contact.

3. Reposition the grinding wheel.

4. Approach the ball, using the $Y$ axis only.

5. Retract from the ball following contact.

Figure 8. WHEEL-SET CYCLE.

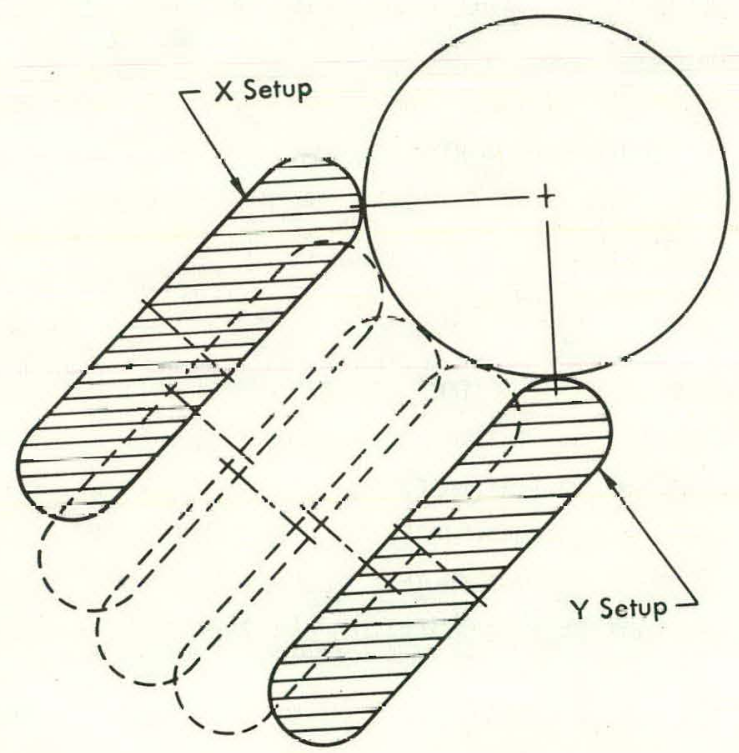

161271

Figure 9. TECHNIQUE USED TO DETERMINE THE EFFECTIVE SHAPE OF A GRINIDING WHEEL. 
actual face radius of $3.25 \mathrm{~mm}(0.128$ in). The curve exhibiting the largest offset values was obtained using a programmed wheel radius of $3.17 \mathrm{~mm}$ $(0.125 \mathrm{in})$, and the curve with the smallest offset was obtained with a programmed radius of $3.25 \mathrm{~mm}(0.128$ in). The curve obtained with the programmed radius of $3.25 \mathrm{~mm}(0.128$ in) shows offsets due to wheel-shape irregularities only, while the curve obtained with the programmed radius of $3.17 \mathrm{~mm}$ (0.125 in) shows offsets due to both wheel-shape irregularities and wheel-size deviation. Subtracting the two curves yields a curve that indicates the offset due to wheel-size deviation alone. As can be seen from Figure 10, the offset at the forty-fivedegree latitude should be $31.5 \mu \mathrm{m}$ $(1.25$ mils $)$ for a wheel-size deviation of $76 \mu \mathrm{m}$ (3 mils). The offset due to wheel-size deviation in Figure 11 matches this value very closely.

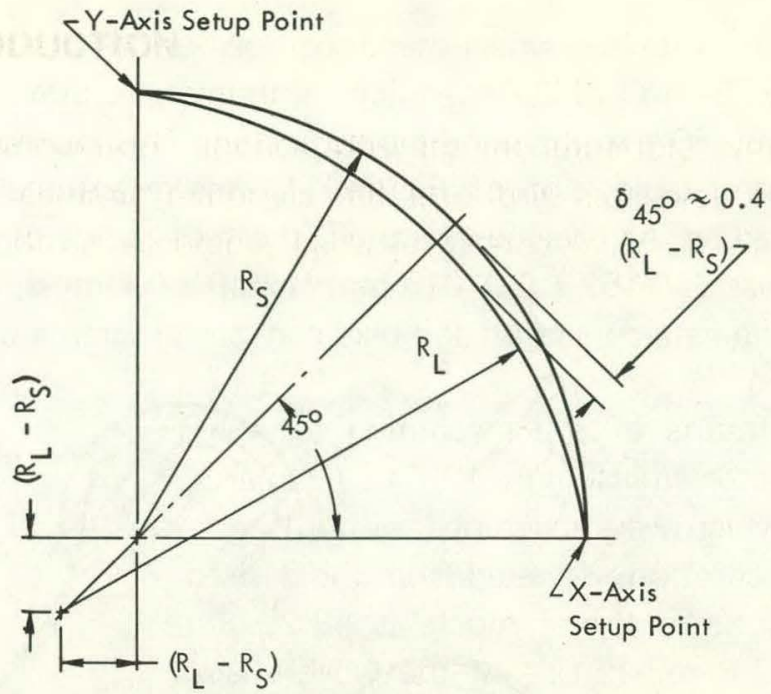

At $45^{\circ}$ :

$$
\begin{aligned}
R_{L}+\delta_{45} & =R_{S}+1.414\left(R_{L}-R_{S}\right) \text {, or } \\
\delta_{45} & =0.414 R_{L}-0.414 R_{S^{\prime}} \text { or } \\
\delta_{45} & =0.414\left(R_{L}-R_{S}\right) .
\end{aligned}
$$

Figure 10. CONTOUR VARIATION RESULTING FROM AN IMPROPER WHEEL-FACE RADIUS.

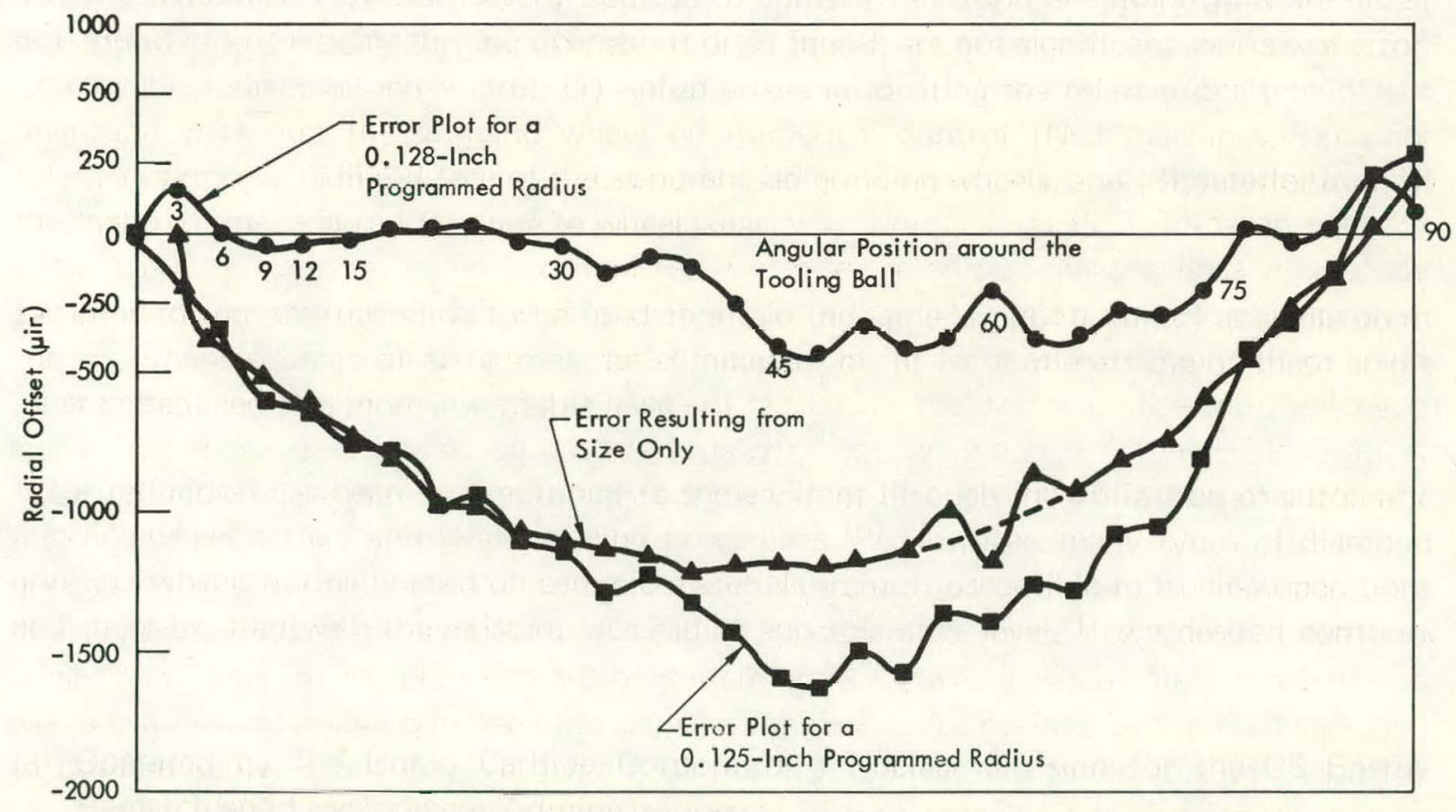

Figure 11. ERROR-TABLE PLOT, SHOWING AN IRREGULAR WHEEL SHAPE AND AN IMPROPER WHEEL-FACE RADIUS. (Numbers on the Top Curve are Degrees of Latitude) 
To test the wheel-shape compensation procedures, several $150-\mathrm{mm}$ (6-in)-diameter by $6.35-\mathrm{mm}$ (0.250-in)-thick aluminum oxide hemishells were contour ground with a 60 - 80-grit diamond-plated wheel. This diamond wheel, the same one used to obtain the error-table plot of Figure 11, was intentionally chosen for its shape and improper face radius. As previously stated, the face radius of the diamond wheel used in the grinding test was $3.27152 \pm 0.01016 \mathrm{~mm}(128.8 \pm 0.4 \mathrm{mils})$, while the programmed wheel radius for both the data-collection and part-contour programs was $3.175 \pm 0 \mathrm{~mm}$ (125 \pm 0 mils).

Results of the machining tests are revealed in Figure 12. The test parts, which were machined without compensation, deviated from the desired contour by as much as $48,26 \mu \mathrm{m}$ (1.8 mils). Use of the wheel-shape compensation techniques reduced this deviation lo $10.16 \mu \mathrm{m} \quad 10.4$ mils). If the part-program tape had been "shimmed" by programming a wheel radius of $3.27152 \mathrm{~mm}$ $(0.1288 \mathrm{in})$, the resultant contour deviation would have been much less. However, since a wheel radius of the nominal size or even two

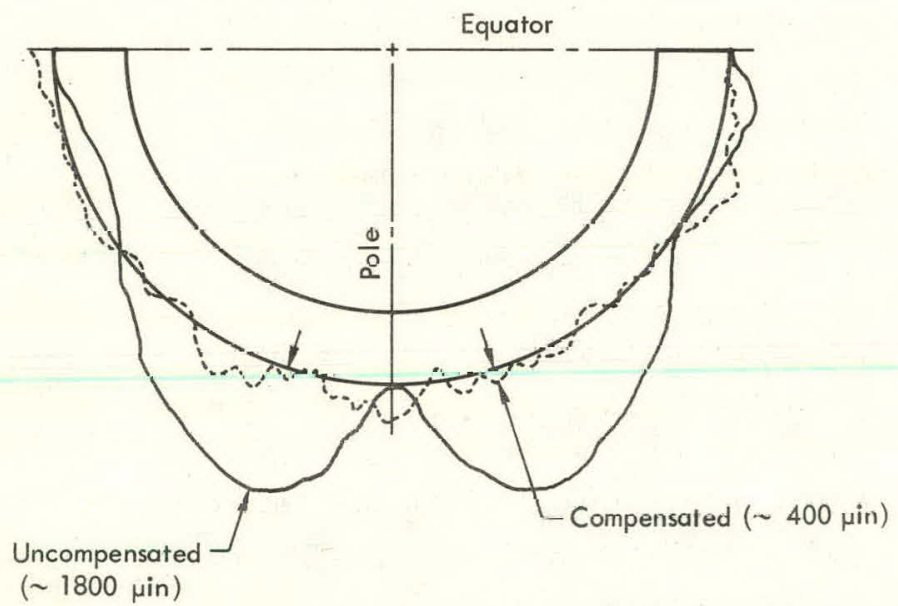

161278

Figure 12. RESULTS OF THE MACHINING TEST. wheels of the same size are rarities, a separate part-program tape would be required for every wheel used. This requirement would not only cause the process to be expensive, but the process would be subject to errors in matching grinding wheels and part-prngram tapes in a production environment.

The initial compensation software inserted the offsets in a step-wise manner when called by the part program. That is, the grinding wheel was moved in the direction nnrmal to the part contour in such a way that the entire offset was implemented all at once. This technique gave satisfactory results as long as the cutting-tool offsets did not change much from one point to the next. However, when the adjacent offset values varied by a larger amount, the compensation technique resulted in steps in the part surface which were larger than desired. Additional wheel-shape compensation software has been purchased that blends the offsets into the programmed tool path and eliminates the sudden perturbations in the part contour.

This software allows the compensation values to be blended into the part-program commands over a number of data blocks ( 0 - 99). This interpolation technique provides an adjusted tool path that is a closer approximation to the one required to obtain the desired part shape. The total peak-to-valley roundness values obtained in grinding tests with the new sultware are still about the same $[12.1 \mu \mathrm{m}(0.5 \mathrm{mil})]$ as with the previous method of compensation, but the adjacent peak-to-valley values are not as high. The tolerance limit using the present ball-wheel setter and the three-degree wheel-shape characterization routine appears to be about $12.7 \mu \mathrm{m}$ (0.5 mil). 
Grinding wheels used in production operations can become very badly worn after a period of time and must either be reshaped, if possible, or discarded. Grinding tests were initiated to determine the point at which automatic wheel-shape-compensation techniques no longer provide acceptable contour tolerances. These tests were conducted using aluminum oxide hemishells and relatively soft resinoid-bonded diamond wheels. Parts machined without wheel-shape compensation, using a moderately worn wheel, resulted in part contours that deviated from the desired true radius by $0.175 \mathrm{~mm}(7$ mils). Parts machined using wheel-shape compensation exhibited 0.015-mm (0.6-mil) contours. In addition, the abrupt changes in the part contour, which were encountered with the step-input compensation process used previously, did not occur. A grinding wheel that was very badly worn was then used. The wheel shape was so poor that the compensation values required to adjust the programmed wheel path were as great as $0.686 \mathrm{~mm}$ (27 mils) in some locations. This wheel had a cross section that appeared to

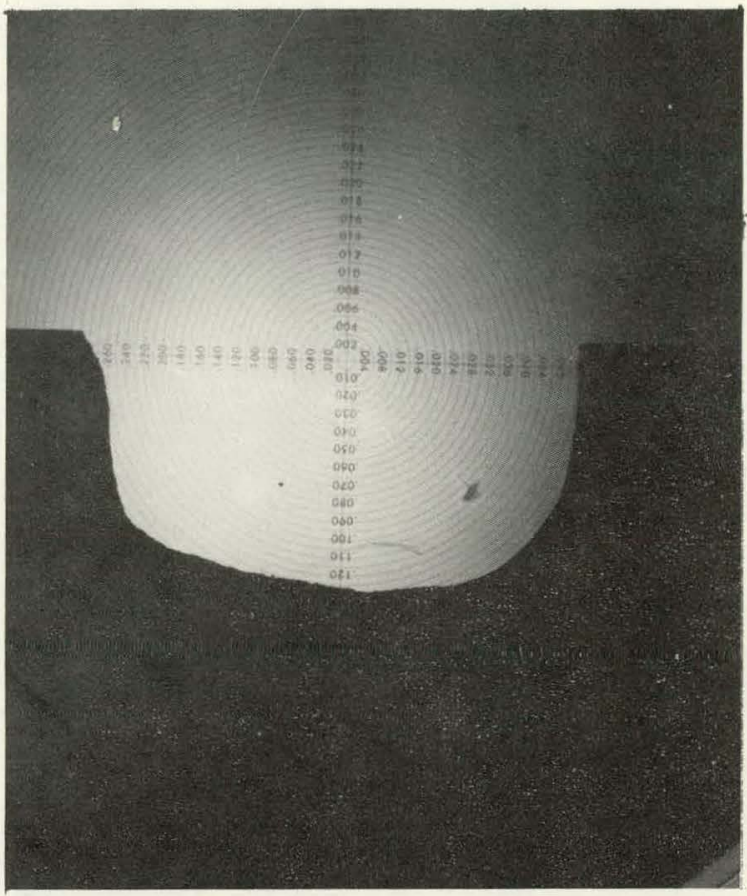

Figure 13. INSPECTION CLIP OF A SEVERELY WORN WHEEL. be almost square (see Figure 13) and would have been discarded in production. Inspection of the test-part contour ground with this wheel, using shape compensation, showed that the part-contour deviation was only $\pm 0.025 \mathrm{~mm}$ ( $\pm 1 \mathrm{mil}$ ). This contour deviation is acceptable on many finished parts and would certainly be acceptable in semifinish operations.

\section{CONCLUSIONS AND RECOMMENDATIONS}

It has been concluded, as a result of this study, that wheel-shape compensation techniques are easily implemented through the use of Computer Numerical Control (CNC), are applicable to all types of contour grinding wheels, allow grinding wheels to be used long after they would normally be discarded due to excessive wear, and improve contour tolerances obtained with both commercially obtained grinding wheels and with worn wheels. In addition, automatic wheel-shape compensation has less potential for error when used on a production basis than does the technique of "shimming" tapes.

Although the work done to date on wheel-shape compensation appears very useful and practical, there are several extensions of this work that should be of equal value. For example, much needs to be done concerning a method for predicting and compensating for in-pass wheel wear that occurs on very hard work materials ground with "soft" wheels. Also, advantages would be realized from a method of stock-removal-rate optimization that would vary the grinding parameters to maintain or increase stock-removal rates when possible. 


\section{ACKNOWLEDGEMENTS}

The authors would like to acknowledge the efforts made by others in the succcssful completion of this project. The software programmers at Allen-Bradley Company were very helpful and innovative in writing the special software required in this work. Their patience in reworking and modifying the software during the heuristic devclopment stages is especially appreciated. The people who developed the in-house programming, Jack Anderson and Miller Taylor, also made significant contributions in critical areas. Without their help, this work would not have been a success. 


\section{APPENDIX A}

\section{OPTIONS AVAILABLE WITH THE COMPUTER NUMERICAL CONTROL SYSTEM}

\section{Axis Calibration}

This option is used to correct differences between the actual slide position and the position indicated by the feedback device, thereby correcting both leadscrew and feedback-device inaccuracies. This option is used in conjunction with the machine-zero feature, which provides a repeatable reference location for the slide-correction values.

\section{Switchable Inch/Metric Conversion}

This option provides the capability to program in metric units if the feedback is in inch units, or vice versa. The conversion is accomplished in software and is controlled by g-codes.

\section{Part Program Storage and Edit}

This option allows part programs to be stored in the computer memory although, for mass storage, disk units can be interfaced to the CNC. The stored programs are entered by means of the tape reader or MDI keyboard and may be executed by calling the desired program via the MDI keyboard. The stored program may also be started at different locations by using the sequence-number search feature. When requested, the CRT will display a program directory showing the names of the stored programs, the amount of memory used for each program, and the total memory remaining.

The CNC will also display program contents and permit editing via the MDI keyboard. Edits may also be stored for use with part programs which are run from tape instead of from memory.

\section{Pattern Repeat}

This option permits segments of a part program to be stored in memory and called for by another part program. The calling part program may be on tape or also stored in memory.

This feature is particularly useful for executing short programs like tool-set cycles or for reducing the storage requirements for a multipass tape. When combined with the cutter-compensation option, a single-pass program can be converted into a multipass program simply by changing the cutter-compensation value between each of the roughing passes. In this case, the master program would consist of a series of cutter-compensation values and calls for the execution of the subprogram, while the actual machining data blocks would be stored as a subroutine. 


\section{Servo and Machine Characteristics}

Several related options are available to improve the machine tool-control system interface. One, gain break, is a standard software feature which reduces the loop gain at velocities above the contouring range and still maintains a high-position loop gain for contouring. The gain-break constants are entered in software on a per-axis basis during the initial setup.

Another, the servo-suppression software feature, reduces the feedrate to every axis if the following error exceeds a preset limit and is restored when the following error is reduced to an acceptable level. If reducing the feed command rate does not reduce the following error, an emergency "stop" condition results. This feature eliminates the chance of machine runaway due to a loss of the feed-back signal.

The third, the machine-limits feature, provides for the storage of machine-travel limits, rate limits, and machine-zero calibrations in the computer memory. These limits and offsets are sampled during a program run to ensure that they are not exceeded.

\section{Cutter-Diameter Compensation}

This option can provide up to 250 cutter-diameter compensation values for use in any of the three planes. It permits the use of tool sizes other than the value which was originally programmed on the part program tape. The offset values may be displayed via the CRT. 


\section{APPENDIX B}

\section{SHAPE COMPENSATION ALGORITHM}

Wheel-shape compensation software is based on the 7300 cutter compensation option.

- However, instead of a single offset per machining pass; multiple cutter offsets are allowed so that corrections may be made for changes in the effective radius of the grinding wheel as.the wheel moves around the part. The correction offsets are obtained by moving the grinding wheel into the tool ball on a radial line. Following contact between the ball and wheel, the CNC notes the position of the $X$ and $Y$ axes and calculates the radial offset (knowing the nominal diameter of the grinding wheel and tool ball). The offsets are stored in a cutter-compensation table and enabled through the use of $t$-codes. The maximum number of offset points is 200 . Figure B-1 illustrates the algorithm that is used to calculate the offsets.

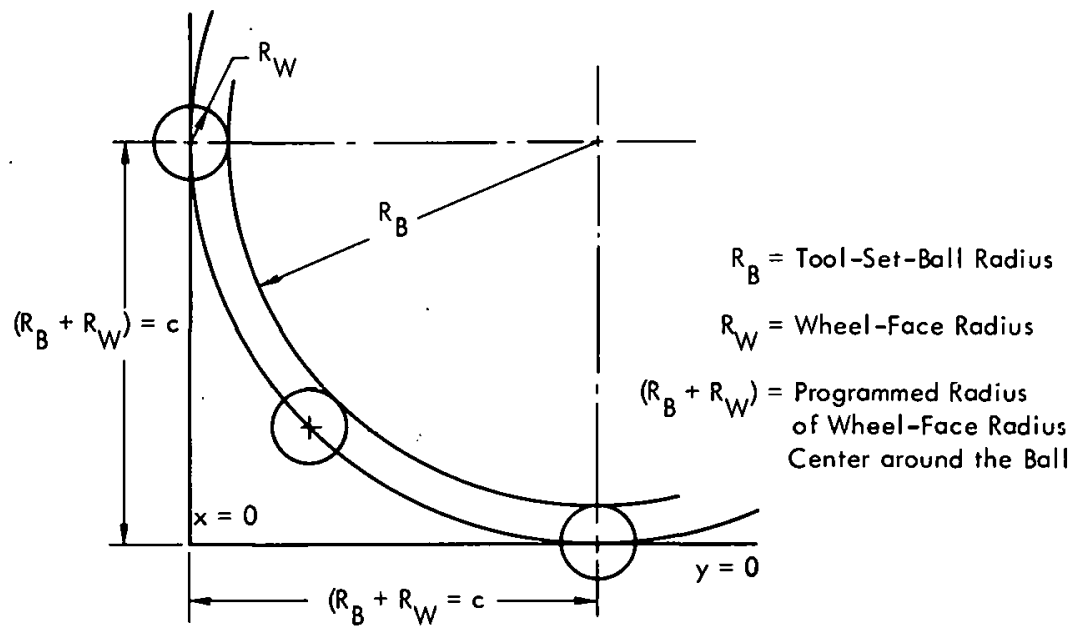

Equation of Circle with Center not at Origin:

$(x-a)^{2}+(y-b)^{2}=c^{2}$

But: $a=b=\left.c\left(R_{B}+R_{W}\right)\right|_{R_{B}=\text { constant; }}$

So: $(x-c)^{2}+(y-c)^{2}=c^{2}$.

Let: $X_{T}$ and $Y_{T}$ be the axes positions at which the wheel touches the ball, then:

$\left(X_{T}-c\right)^{2}+\left(Y_{T}-c\right)^{2}-c^{2}=$ offset.

Figure B-1. OFFSET ALGORITHM.

164500

Data stored in the cutter-compensation table are cataloged under the wheel-set-ball normal at which it was obtained. This listing is done through the use of a t-code that is generated by the postprocessor. The postprocessor also examines the normal cut vector during generation of the machining part program and outputs the appropriate $t$-word for each part program block. In addition, the postprocessor also outputs an $\mathrm{H}$ code which tells the CNC how many part-program blocks will occur before a new t-code is issued. This total determines the number of blocks over which a particular offset is 
blended. Modal g-codes have been included to inhibit the interpolation of an offset into a particular block as would be required for straight-line segments such as cylindrical sections, tapers, and faces.

During the data-collection pass, the rotating grinding wheel approaches the wheel-set ball at least twice at each location. The initial approach speed is faster than the second and is used to locate the wheel-set ball. The wheel is then retracted $25: 4 \mu \mathrm{m}$ ( 2 mils) and the process is repeated at a slower feedrate for the final setup. This dual-approach procedure also allows the software to compare the offsets calculated after each of the passes to verify the validity of the data. In this manner, erroneous offset data caused by false triggering of the wheel setter, due to environmental disturbances, is detected and the data-collection process is repeated at the invalid setup point. 


\section{Distribution}

Energy Research and Development

Administration - Oak Ridge

Hickman, H. D.

Leed, R. E.

Zachry, D. S., Jr

Lawrence Livermore Laboratory

Bryan, J. B.

Chapman, W. H.

Jepson, J. O.

Nelson, W. E.

Los Alamos Scientific Laboratory

Hoyt, H. C.

Oak Ridge Gaseous Diffusion Plant

Stief, S. S.

Wilcox, W. J., Jr

\section{Oak Ridge National Laboratory}

Weir, J. R., Jr

Oak Ridge Y-12 Plant

Alvey, H. E.

Anderson, P. J.

Armstrong, R. C.

Barkman, W. E. (10)

Bookhart, T. W.

Burditt, R. B.

Burkhart, L. E./Mason, D. L.

Butturini, W. G.

Dawson, D. 0.

Duggan, H. G.

Foulk, O.L.

Fraser, R. J.

Gritzner, V. B.

Hensley, C. E.

Hurst, J. S.

Jones, F. W.

Kahl, K. G.

Keith, A.

Kite, H. T. (25)

Mariớw, G. B.
Martin, W. R./Googin, J. M.

Mills, J. M., Jr

Morris, T. O. (15)

Murphy, S. M., Jr

Oliphant, G.W.

Pearson, K. O.

Perry, A. E.

Phillips, L. R.

Smith, H. F., Jr

Smith, R. D.

Steger, P. J.

Stoner, H. H.

Tewes, W. E.

Thompson, C. H.

Tilson, F. V.

Weathersby, W. E.

Whitson, W. K.

Whitton, L. G., Jr

Wright, C. C.

Y-12 Central Files (master copy)

$Y-12$ Central Files (route copy)

$Y-12$ Central Files (Y-12RC)

$Y-12$ Central Files (5)

Paducah Gaseous Diffusion Plant

Millican, R. M.

Union Carbide Corporation - New York

Winters, Charles

Union Carbide Corporation-Parma

Research Center

Chambers, W. E.

University of Tennessee-College

of Engineering

Stansbury, E. E.

In addition, this report is distributed in accordance with the category UC-38, Engineering and Equipment, as given in the USERDA Standard Distribution Lists for Unclassified Scientific and Technical Reports, TID-4500. 